\title{
PENGARUH KEPRIBADIAN DAN KEMAMPUAN INTELEKTUAL TERHADAP KOMPETENSI GURU DI SMKN 3 KOTA BENGKULU
}

\author{
Sentia Rapika \\ Anggri Puspita Sari \\ Fakultas Ekonomi dan Bisnis Universitas Bengkulu
}

\begin{abstract}
The purposes of this study examines the effect of personality and intellectual ability on teacher competence in SMKN 3 Bengkulu city. This research was conducted in SMKN 3 Bengkulu City with the object of research is permanent teachers or civil servants. The sample used in this study was 74 respondents using purposive sampling technique. Data analysis technique using multiple regression analysis and using SPSS 17.0 sofware. Research design using survey explanatory, the method in this study using factor analysis to test the validity of the data and using Cronbach's alpha to test the reliability of the data. The results of this research shows that the personality and intellectual ability partially have positive and signifikan effect on the teacher competence. Personality and intellectual ability simultaneously have significant effect on the teacher competence in SMKN 3 Bengkulu city.
\end{abstract}

Keywords: personality, intellectual ability, teacher competence.

\section{PENDAHULUAN}

\section{Latar Belakang}

Kompetensi menurut Spencer \& Spencer (1993) adalah sebagai karakteristik dasar yang dimiliki oleh seorang individu yang berhubungan secara kausal dalam memenuhi kriteria yang diperlukan dalam menduduki suatu jabatan. Ada 5 (lima) karakteristik yang membentuk kompetensi yakni (1) Faktor pengetahuan meliputi masalah teknis, administratif, proses kemanusiaan, dan sistem, (2) Keterampilan; merujuk pada kemampuan seseorang untuk melakukan suatu kegiatan, (3) Konsep diri dan nilai-nilai; merujuk pada sikap, nilai-nilai dan citra diri seseorang, seperti kepercayaan seseorang bahwa dia bisa berhasil dalam suatu situasi, (4) Karakteristik pribadi; merujuk pada karakteristik fisik dan konsistensi tanggapan terhadap situasi atau informasi, seperti pengendalian diri dan kemampuan untuk tetap tenang dibawah tekanan, (5) Motif yaitu merupakan emosi, hasrat, kebutuhan psikologis atau dorongan-dorongan lain yang memicu tindakan. 
Zwell (2000) mengemukakan beberapa faktor yang dapat mempengaruhi kecakapan kompetensi seseorang yaitu : (1) Keyakinan dan nilai, keyakinan seseorang terhadap dirinya maupun terhadap orang lain mempengaruhi perilakunya, (2) Keterampilan, pengembangan keterampilan yang secara spesifik berkaitan dengan kompetensi dapat berdampak pada budaya organisasi dan kompetensi individual, (3) Pengalaman, keahlian dari banyak kompetensi memerlukan pengalaman mengorganisasi orang, komunikasi di hadapan kelompok, menyelesaikan di hadapan kelompok, menyelesaikan masalah dan sebagainya, (4) Karakteristik kepribadian, banyak faktor kepribadian yang tidak dapat berubah walaupun demikian dalam kepribadian bukan sesuatu yang tidak dapat berubah, (5) Motivasi, merupakan faktor kompetensi dengan memberikan dorongan, apresiasi dan pengakuan, (6) Isu emosional, hambatan emosional dapat membatasi penguasaan kompetensi sedangkan mengatasi pengalaman tidak mneyenangkan akan memperbaiki penguasaan dalam banyak kompetensi, (7) Kemampuan intelektual, kompetensitergantung pada pemikiran kognitif seperti pemikirankonseptual dan pemikiran analitis.

Hasil penelitian Hornby and Thomas (1989: 53) dan Becher el al. (2001 : 156) menyatakan bahwa kompetensi sebagai pengetahuan, keahlian, kemampuan, atau karakteristik pribadi individu yang mempengaruhi secara langsung kinerja pekerjaan. Hasil studi Kak et al. (2001), bahwa kemampuan intelektual menjadikan individu mempunyai kompetensi meliputi pengetahuan, keterampilan, kemampuan dan ciri. Itu diperoleh dari profesi layanan melalui pre-service pendidikan, dalam jabatan pelatihan dan pengalaman kerja serta standar hubungan antar pribadi dapat dicapai dengan hasil kerja yang tinggi.

Berdasarkan beberapa pengertian kompetensi oleh beberapa ahli dapat disimpulkan bahwa kompetensi merupakan suatu karakteristik yang dimiliki oleh seorang individu yang dipengaruhi oleh pengetahuan, keahlian, kemampuan dan karakteristik kepribadian.Dimana Kompetensi guru menurut, Broke dan Stone (1995) (Mulyasa 2008 : 25) mengemukakan bahwa Kompetensi guru sebagai ... descriptive of qualitative of nature of teacher appears to be entirely meaningful... Kompetensi guru merupakan gambaran kualitatif tentang harkat perilaku guru yang penuh arti.Jadi dapat diambil kesimpulan bahwa kerpribadian dan kemampuan intelektual memiliki pengaruh terhadap kompetensi.

Kepribadian menurut Allport Kepribadian adalah suatu organisasi yang dinamis dari sistem psiko-fisik individu yang menentukan tingkah laku dan pemikiran indvidu secara khas. Menurut Goleman (2002: 512), mengatakan bahwa kemampuan intelektual adalah kemampuan untuk mengenali perasaan kita sendiri dan perasaan orang lain, kemampuan memotivasi diri sendiri dan kemampuan mengelola emosi dengan baik pada diri sendiri dan dalam hubungan dengan orang lain.

Faktor kepribadian dan kemampuan intelektual juga mempengaruhi kompetensi guru di SMKN 3 kota Bengkulu yang beralamat di jalan Jati no 42, Padang Jati Sawah Lebar kota Bengkulu, merupakan salah satu sekolah negeri kejuruan yang memiliki jurusan (kompetensi keahlian) yaitu : tata busana butik, tata kecantikan kulit dan 
rambut , tata boga , TKJ (teknik komputer jaringan), dan broadcasting.Berdasarkan pra-survei yang dilakukan,dengan mewawancarai 5 orang guru dan 4 orang siswa,menunjukan bahwa kompetensi setiap guru di SMKN 3 kota Bengkulu berbeda-beda tergantung bagaimana profesionalisme mereka dalam mengajar dikelas, salah seorang guru menerangkan bahwa kepribadian yang dimiliki guru sangat berperan penting dalam kegiatan belajar mengajar dan memang masih ditemukannya beberapa orang guru yang bersikap acuh tak acuh pada siswa-siswi dalam kegiatan proses pembelajaran di kelas hal ini menyebabkan proses pembelajaran kurang maksimal dan ilmu tidak tersampaikan sepenuhnya, hal ini erat kaitannya dengan kompetensidan kepribadian guru.

Dalam hal penyampaian materi saat proses pembelajaran, beberapa guru yang memiliki tingkat pendidikan yang tinggi, lebih menerapkan sistem pembelajaran dimana murid dituntut untuk belajar mandiri dengan penjelasan yang sangat singkat, hal ini cenderung akan membuat siswa-siswi tidak suka untuk belajar. Lalu juga ditemukan bahwa guru akan lebih memahami karakteristik siswa yang aktif dikelas mereka. Beberapa siswa menyatakan bahwa mereka lebih menyukai guru yang atraktif dalam mengajar, hal ini sangat erat kaitannya dengan skill, keahlian, pengetahuan dan ini berhubungan dengan kemampuan guru itu sendiri. Berdasarkan teori tersebut maka tujuan penelitian ini adalah menganalisis pengaruh kepribadian dan kemampuan intelektual terhadap kompetemsi guru di SMKN 3 Kota Bengkulu.

\section{TINJAUAN PUSTAKA}

\section{Kompetensi}

Kompetensi sangat erat kaitannya dengan keahlian atau kemampuan, keterampilan, knowledge, dan karakterisik kepribadian seorang individu yang berkaitan dengan bagaimana seseorang melaksanakan suatu pekerjaan yang dimilikinya.

\section{Pengertian Kompetensi}

Kompetensi adalah suatu kemampuan untuk melaksanakan ataumelakukan suatu pekerjaan atau tugas yang dilandasi atas keterampilan dan pengetahuan serta didukung oleh sikap kerja yang dituntut oleh pekerjaan tersebut. Kompetensi sebagai kemampuan seseorang untuk menghasilkan pada tingkat yang memuaskan di tempat kerja, juga menunjukkan karakteristik pengetahuan dan keterampilan yang dimiliki atau dibutuhkan oleh setiap individu yang memampukan mereka untuk melakukan tugas dan tanggung jawab mereka secara efektif dan meningkatkan standar kualitas professional dalam pekerjaan. Ada dua istilah yang muncul dari dua aliran yang berbeda tentang konsep kesesuaian dalam pekerjaan. Istilah tersebut adalah "Competency" (kompetensi) yaitu deskripsi mengenai perilaku, dan "Competence" (kecakapan) yang merupakan deskripsi tugas atau hasil pekerjaan. (Palan, 2007:5). 
Pengertian kompetensi sebagai kecakapan atau kemampuan juga dikemukakan oleh. Roe (2001:73) sebagai berikut : Competence is defined as the ability to adequately perform a task, duty or role. Competence integrates knowledge, skills, personal values and attitudes. Competence builds on knowledge and skills and is acquired through work experience and learning by doing" Kompetensi dapat digambarkan sebagai kemampuan untuk melaksanakan satu tugas, peran atau tugas, kemampuan mengintegrasikan pengetahuan, ketrampilan-ketrampilan, sikap-sikap dan nilainilai pribadi, dan kemampuan untuk membangun pengetahuan dan keterampilan yang didasarkan pada pengalaman dan pembelajaran yang dilakukan.

Kompetensi Robbins (2007:38) bahwa kompetensi adalah "kemampuan (ability) atau kapasitas seseorang untuk mengerjakan berbagai tugas dalam suatu pekerjaan, dimana kemampuan ini ditentukan oleh 2 (dua) faktor yaitu kemampuan intelektual dan kemampuan fisik. Menurut Undang-Undang Nomor 14 Tahun 2005 tentang Guru Dan Dosen, "Kompetensi adalah seperangkat pengetahuan, keterampilan, dan perilaku yang harus dimiliki, dihayati, dan dikuasai oleh guru atau dosen dalam melaksanakan tugas keprofesionalan."

Dari teori beberapa ahli mengenai kompetensi dapat disimpulkan bahwa kompetensi guru merupakan bagaimana karakteristik yang mendasari perilaku dari seorang guru yang berkaitan dengan kemampuan, keterampilan, pengetahuan, dan aspek lainnya guna meningkatkan mutu pendidikan.

\section{Faktor-faktor yang Mempengaruhi Kompetensi}

Zwell (2000) mengungkapkan bahwa terdapat beberapa faktor yang dapat memengaruhi kecakapan kompetensi seseorang, yaitu sebagai berikut:

1. Keyakinan dan Nilai-nilai

Keyakinan terhadap diri maupun terhadap orang lain akan sangat memengaruhi perilaku. Apabila orang percaya bahwa mereka tidak kreatif dan inovatif, mereka tidak akan berusaha berpikir tentang cara baru atau berbeda dalam melakukan sesuatu

2. Keterampilan

Keterampilan memainkan peranan di berbagai kompetensi. Berbicara di depan umum merupakan keterampilan yang dapat dipelajari, dipraktikkan, dan diperbaiki. Keterampilan menulis juga dapat diperbaiki dengan instruksi, praktik dan umpan balik.

3. Pengalaman

Keahlian dari banyak kompetensi memerlukan pengalaman mengorganisasi orang, komunikasi di hadapan kelompok,menyelesaikan masalah, dan sebagainya. Orang yang tidak pernah berhubungan dengan organisasi besar dan kompleks tidak mungkin mengembangkan kecerdasan organisasional untuk memahami dinamika kekuasaan dan pengaruh dalam lingkungan tersebut.

4. Karakteristik Kepribadian

Dalam kepribadian termasuk banyak faktor yang di antaranya sulit untuk berubah. Akan tetapi, kepribadian bukannya sesuatu yang tidak dapat berubah. Kenyataannya, kepribadian seseorang dapat berubah sepanjang waktu. Orang merespon dan berinteraksi dengan kekuatan dan lingkungan sekitarnya. 


\section{Motivasi}

Motivasi merupakan faktor dalam kompetensi yang dapat berubah. Dengan memberikan dorongan, apresiasi terhadap pekerjaan bawahan, memberikan pengakuan dan perhatian individual dari atasan dapat mempunyai pengaruh positif terhadap motivasi seseorang bawahan.

6. Isu Emosional

Isu emosional dapat membatasi penguasaan kompetensi.

Takut membuat kesalahan, menjadi malu, merasa tidak disukai atau tidak menjadi bagian, semuanya cenderung membatasi motivasi dan inisiatif. Perasaan tentang kewenangan dapat mempengaruhi kemampuan komunikasi dan menyelesaikan konflik dengan manajer. Orang mungkin mengalami kesulitan mendengarkan orang lain apabila mereka tidak merasa didengar.

7. Kemampuan Intelektual

Kompetensi tergantung pada pemikiran kognitif seperti pemikiran konseptual dan pemikiran analitis. Tidak mungkin memperbaiki melalui setiap intervensi yang diwujudkan suatu organisasi. Sudah tentu faktor seperti pengalaman dapat meningkatkan kecakapan dalam

kompetensi ini.

8. Budaya Organisasi, budaya organisasi memengaruhi kompetensi sumber daya manusia

\section{Kepribadian}

Kepribadian meliputi segala corak perilaku dan sifat yang khas dan dapat diperkirakan pada diri seseorang atau lebih bisa dilihat dari luar, yang digunakan untuk bereaksi dan menyesuaikan diri terhadap rangsangan, sehingga corak tingkah lakunya itu merupakan satu kesatuan fungsional yang khas bagi individu itu, seperti bagaimana kita bicara, penampilan fisik, dan sebagainya.

\section{Pengertian Kepribadian}

Kepribadian menurut Allport adalah Organisasi dinamis dalam individu sebagai sistem psikofisik individu yang menentukan caranya yang khas dalam menyesuaikan diri terhadap lingkungannya. Horton (1982:12) mendefinisikan bahwa kepribadian adalah keseluruhan sikap, perasaan, ekspresi dan temperamen seseorang. Kepribadian menurut Robbins (2007) adalah sebagai organisasi dinamis dalam sistem psikologis individu yang menentukan caranya untuk menyesuaikan diri secara unik terhadap lingkungannya. Sedangkan menurut Cattel (1965: 27), kepribadian adalah apa yang menentukan perilaku dalam situasi yang ditetapkan dan dalam kesadaran jiwa yang ditetapkan. Dapat disimpulkan kepribadian adalah ciri, karakteristik, gaya atau sifat-sifat yang memang khas dikaitkan dengan diri berdasarkan lingkungannya dan kepribadian itu sebetulnya adalah campuran dari hal-hal yang bersifat psikologis, kejiwaan dan juga yang bersifat fisik. 


\section{Big Five Personality Traits Model(Model Lima Besar)}

Big Five Personality Traits Model yang dikemukakan oleh L. Goldberg. Teori Sifat Kepribadian Model Lima Besar atau Big Five Personality Traits Model tersebut terdiri dari 5 dimensi kunci yaitu Openness, Conscientiousness, Extraversion/Introversion, Agreeableness dan Natural Reactions. Penjelasan dari model lima besar (Big Five Personality Traits Model) yaitu sebagai berikut :

1. Openness to Experience (Terbuka terhadap Hal-hal baru)

Dimensi Kepribadian Opennes to Experience ini mengelompokan individu berdasarkan ketertarikannya terhadap hal-hal baru dan keinginan untuk mengetahui serta mempelajari sesuatu yang baru. Karakteristik positif pada Individu yang memiliki dimensi ini cenderung lebih Imangination (imajinasi), Artistic Interest (minat artistik), Emotionality (emosional), Intellect (kecerdasan), Adventurousness (petualang), danLiberalis (liberalism).Sifat kebalikan dari Openness to Experience ini adalah individu yang cenderung konvensional dan nyaman terhadap hal-hal yang telah ada,

2. Conscientiousness (Sifat Berhati-hati)

Individu yang memiliki Dimensi Kepribadian Conscientiousness ini cenderung lebih berhati-hati dalam melakukan suatu tindakan ataupunpenuh pertimbangan dalam mengambil sebuah keputusan, mereka juga memiliki disiplin diri yang tinggi dan dapat dipercaya. Karakteristik Positif pada dimensi adalah Self-dicipline (disiplin diri), Dutifulnes (patuh), Self Efficacy (efikasi diri), Orderliness (teratur), Coutiosness (kehati-hatian) dan Achievment Striving (pecanpaian pretasi). Sifat kebalikan dari Conscientiousness adalah individu yang cendurung kurang bertanggung jawab, terburu-buru, tidak teratur dan kurang dapat diandalkan dalam melakukan suatu pekerjaan.

\section{Extraversion (Ekstraversi)}

Dimensi Kepribadian Extraversion ini berkaitan dengan tingkat kenyamanan seseorang dalam berinteraksi dengan orang lain. Karakteristik Positif Individu Extraversion adalah Gregariousness (suka berkumpul), Activity Level (aktivitas yang tinggi), Assertiveness (arsetif), Excitement seeking (mencari kesenangan), Cheerfulness (ceria), Friendliness (ramah). Sebaliknya, Individu yang Introversion (Kebalikan dari Extraversion) adalah mereka yang pemalu, suka menyendiri, penakut dan pendiam.

4. Agreeableness (Mudah Akur atau Mudah Bersepakat)

Individu yang berdimensi Agreableness ini cenderung lebih patuh dengan individu lainnya dan memiliki kepribadian yang ingin menghindari konfilk. Karakteristik Positif-nya adalah Moraity (moralitas), Trust (kepercayaan), Altruism (pengorbankan), Modesty (kesopanan), Sympathy (simpati), Cooperation(kerjasama). Karakteristik sebaliknya adalah mereka yang tidak mudah bersepakat dengan individu lain karena suka menentang, bersifat dingin dan tidak ramah.

5. Neuroticism (Neurotisme)

Neuroticism adalah dimensi kepribadian yang menilai kemampuan seseorang dalam menahan tekanan atau stress. Karakteristik Positif dari Neuroticism disebut dengan Emotional Stability (Stabilitas Emosional), Individu dengan Emosional yang stabil cenderang Tenang saat menghadapi masalah, percaya diri, memiliki pendirian yang teguh. Sedangkan karakteristik kepribadian Neuroticism (karakteristik Negatif) 
adalah mudah gugup, depresi, tidak percaya diri dan mudah berubah pikiran. Oleh karena itu, Dimensi Kepribadian Neuroticism atau Neurotisme yang pada dasarnya merupakan sisi negatif ini sering disebut juga dengan dimensi Emotional Stability (Stabilits Emosional) sebagai sisi positifnya, ada juga yang menyebut Dimensi ini sebagai Natural Reactions (Reaksi Alami).

\section{Kemampuan Intelektual}

Kemampuan intelektual merupakan suatu keahlian atau kapasitas bagaimana seorang individu tersebut menjalankan kegiatanya sehari-hari dengan berpikir jernih berdasarkan ilmu pengetahuan.

\section{Pengertian Kemampuan Intelektual}

Kemampuan menunjukkan potensi orang untuk melaksanakan tugas atau pekerjaan. Kemampuan itu mungkin dimanfaatkan atau mungkin juga tidak, kemampuan berhubungan erat dengan kemampuan fisik dan mental yang dimiliki orang untuk melaksanakan pekerjaan dan bukan yang ingin dilakukannya Gibson (1994:104). Menurut Robbins (2001:46), kemampuan intelektual adalah kemampuan mental yang diperlukan untuk menjalankan kegiatan mental. Dapat disimpulkan bahwa kemampuan intelektual merupakan bagaimana seorang individu menjalankan kegiatan mental serta berpikiran jernih berdasarkan ilmu pengetahuan.

\section{Dimensi Kemampuan intelektual}

Spencer and Spencer(1993 : 25-26)(Rachman 2012) dengan 3 dimensi-dimensi yakni berpikir analitis, berpikir konseptual, keahlian teknis secara profesional.

1. Berpikir analitis (analytical thinking), yakni kemampuan memahami situasi atau permasalahan dengan cara memandangnya sebagai satu kesatuan mencakupkemampuan untuk mengidentifikasi masalah mendasar dalam situasi kompleks.

2. Berpikir konseptual (conceptual thinking), yakni kemampuan memahami situasi atau keadaan dengan cara memandangnya sebagai satu kesatuan yang terintegrasi mencakup kemampuan mengidentifikasi pola keterikatan antara masalah yang tidak tampak dengan jelas atau kemampuan mengidentifikasikan permasalahan utama yang mendasar dalam situasi yang kompleks.

Keahlian teknis secara profesional (technical/professional/managerial expertise), yakni penguasaan pengetahuan eksplisit, berupa keahlian/keterampilan untuk menyelesaikan suatu pekerjaan serta motivasi untuk mengembangkan, menggunakan dan mendistribusikan pengetahuan atau keterampilan kepada orang lain.

\section{METODE PENELITIAN}

Jenis Penelitian yang digunakan dalam penelitian ini adalah penelitian kuantitatif dengan menggunakan pendekatan Explanatory survey. Metode pengumpulan data yang digunakan dalam penelitian ini adalah dengan menggunakan kuesioner, Skala 
pengukuran yang digunakan adalah skala likert dimana skala likert menurut Sugiyono (2014:134) adalah Skala likert digunakan untuk mengukur sikap, pendapat dan persepsi seseorang atau sekelompok orang tentang fenomena social." Populasi dari penelitian ini adalah semua guru di SMKN 3 kota Bengkulu dengan populasi sebanyak 100 orang.

Dalam penelitian ini penulis menggunakan metode purposive sampling, purposive sampling adalah metode penarikan sample dengan beberapa pertimbangan tertentu yang bertujuan agar data yang diperoleh nantinya bisa lebih representatif. Pertimbangan yang digunakan adalah guru berstatus PNS atau pegawai negerti sipil yaitu sebanyak 81 orang responden. Teknik analisis data yang digunakan dalam penelitian ini adalah dengan teknik analisis regresi linier berganda.

\section{HASIL DAN PEMBAHASAN}

Hasil dari penelitian yang telah dilakukan mengenai kepribadian, kemampuan intelektual dan kompetensi guru menunjukan bahwa ada pengaruh yang signifikan dan positif antara kepribadian dan kemampuan intelektual terhadap kompetensi guru. Sehingga semakin baik atau tinggi variabel kepribadian dan kemampuan intelektual maka akan semakin meningkat juga variabel kompetensi guru dan pengaruh diantara ketiga variabel tersebut adalah positif. Hal ini memberikan kesimpulan bahwa kepribadian dan kemampuan intelektual yang tinggi maka kompetensi guru juga akan lebih baik untuk menunjang pekerjaan mereka sebagai seorang guru, seperti halnya kemampuan mereka dalam berpikir untuk memahami keadaan, karakteristik siswa-siswinya. Serta mereka bisa menerapkan pengetahun dan keahlian mereka sesuai dengan kebutuhan siswa-siswinya dan memiliki pemahaman dari materi pembelajaran yang ingin disampaikan dan pengembangan pengetahuan yang mereka miliki sebagai guru.

Pada tanggapan guru sebagai responden memperlihatkan bahwa persepsi mereka mengenai kepribadian dan kemampuan intelektual menunjukan, bahwa variabel kepribadian dan kemampuan intelektual memiliki nilai rata-rata yang tinggi. sehingga terlihat adanya indikasi positif yang terjadi ketika kepribadian dan kemampuan intelektual tinggi, maka kompetensi guru juga akan cenderung lebih baik. Tetapi pada variabel kepribadian terlihat bahwa dimensi openess to experience memiliki skor rata-rata terendah diantara dimensi lainnya, meskipun termasuk dalam ketegori tinggi, tapi hal ini harus menjadi catatan khusus bagi para guru untuk lebih memberikan kebebasan atau memberikan ruang bagi orang-orang disekitarnya dan lebih terbuka serta ramah dengan orang lain baik didalam maupun diluar sekolah. Sedangkan pada variabel kemampuan intelektual terlihat bahwa dimensi berpikir analitis (analytical thinking) memiliki skor rata-rata terendah 
diantara dimensi lainnya, termasuk dalam ketegori cukup tinggi, guru harus lebih mengembangkan kemampuan mereka dalam memahami suatu permasalahan yang terjadi baik tentang pekerjaan maupun urusan pribadi.

\section{KESIMPULAN DAN SARAN}

\section{Kesimpulan}

Berdasarkan hasil penelitian dan pembahasan yang telah dikaji secara empiris tentang kepribadian, kemampuan intelektual dan kompetensi guru, maka kesimpulan dari penelitian ini adalah :

1. Kepribadian dan kemampuan intelektual berpengaruh secara positif dan signifikan terhadap kompetensi guru di SMKN 3 Kota Bengkulu. Artinya jika kepribadian dan kemampuan intelektual tinggi atau baik maka kompetensi guru juga akan meningkat begitu juga sebalikya jika kepribadian dan kemampuan intelektual rendah atau buruk maka kompetensi guru juga akan menurun.

2. Kepribadian berpengaruh secara positif dan signifikan terhadap kompetensi guru di SMKN 3 Kota Bengkulu. Artinya jika kepribadian tinggi atau baik maka kompetensi guru juga akan meningkat begitu juga sebalikya jika kepribadian rendah atau buruk maka kompetensi guru juga akan menurun.

3. Kemampuan intelektual berpengaruh secara positif dan signifikan terhadap kompetensi guru di SMKN 3 Kota Bengkulu. Artinya jika kemampuan intelektual tinggi atau baik maka kompetensi guru juga akan meningkat begitu juga sebalikya jika kemampuan intelektual rendah atau buruk maka kompetensi guru juga akan menurun.

\section{Saran}

Berdasarkan kesimpulan yang telah dijelaskan diketahui bahwa adanya pengaruh yang positif dan signifikan diantara variabel kepribadian, kemampuan intelektual dan kompetensi guru. Maka peneliti memberikan saran yang perlu dipertimbangkan sehingga kedepannya SMKN 3 Kota Bengkulu semakin baik nantinya. Saran-saran yang dapat menjadi pertimbangan pihak sekolah adalah sebagai berikut :

1. Guru-guru di SMKN 3 Kota Bengkulu harus terus menjadi pribadi yang semakin baik kedepannya sebagai seorang staf pengajar, memiliki 
perhatian yang tinggi bagi siswa-siwinya dan untuk terus berusaha memberikan pengajaran yang baik agar terciptanya generasi-generasi baru yang mampu untuk menjadi seseorang yang berguna baik untuk dirinya ataupun orang-orang disekitarnya. Serta pada variabel kepribadian juga terlihat bahwa dimensi openess to experience memiliki skor rata-rata terendah diantara dimensi lainnya sehingga dalam hal ini diharapkan seluruh guru dan pihak sekolah untuk lebih memberikan ruang bagi orang disekitar mereka dan meningkatkan kehidupan sekolah yang lebih aktraktif dibandingkan dengan hal-hal yang telah ada selama ini seperti dengan meningkatkan minat artistik bagi siswa-siswinya.

2. Terus mengembangkan kemampuan intelektual dari guru-guru di SMKN 3 Kota Bengkulu, ada baiknya pihak sekolah SMKN 3 Kota Bengkulu untuk selalu memberikan pelatihan-pelatihan seperti pelatihan keahlian, bagaimana untuk menjadi guru yang mampu berpikir tentang penguasaan dan memahami pekerjaan bagi guru-guru, untuk menjadi guru yang memiliki kemampuan intelektual yang baik. Serta pada variabel kemampuan intelektual terlihat bahwa dimensi conceptual thinking memiliki skor terendah diantara dimensi lainnya sehingga dalam hal ini diharapkan untuk para guru untuk terus meningkatkan pemahaman mereka tentang permasalahan apa yang terjadi baiknya berkaitan dengan proses pembelajaran dengan siswa-siswi, dengan sesama rekan guru dan wali siswa untuk menentukan keputusan yang sebaiknya harus diambil.

3. Kompetensi sangat dibutuhkan oleh para guru untuk melaksanakan pekerjaan mereka sebagai seorang tenaga pengajar dan tentunya guru di SMKN 3 Kota bengkulu untuk terus meningkatan kompetensi mereka mencakup pemahaman tentang peserta didik, materi pembelajaran, kepercayaan diri mereka dengan cara belajar dari pengalaman yang mereka miliki, pelatihan kompetensi, mengikuti ujian kompetensi yang diadakan oleh pemerintah dan hal lainnya yang dapat meningkatkan tingkat kompetensi mereka sebagai seorang guru. Serta pada variabel kompetensi guru terlihat bahwaa dimensi kompetensi kepribadian memiliki skor terendah diantara dimensi lainnya sehingga dalam hal ini diharapkan agar guru untuk terus meningkatkan kepercayaan diri, sikap yang diambil, wibawa sebagain seorang guru serta hal lainnya yang terkait dengan kepribadin seorang guru.

4. Penelitian yang saat ini dilakukan hanya menggunakan 74 responden dalam satu sekolah yaitu SMKN 3 Kota Bengkulu. Untuk peneliti yang ingin melakukan penelitian yang sama untuk kedepannya ada baiknya 
menambahh jumlah responden dan ruang lingkup dan generalisasi penelitian menjadi semakin luas sehingga hasil penelitian yang diperoleh lebih komprehensif dan memperoleh respresentatif sesuai dengan apa yang hendak diukur dalam penelitian serta untuk menambah variabel yang terkait dengan kompetensi yang tidak diteliti dalam penelitian ini seperti : keyakinan dan nilai-nilai, keterampilan, pengalaman, motivasi, isu emosional dan budaya organisasi.

\section{DAFTAR PUSTAKA}

Arif, I.A, 2013. Analisis Kompetensi Guru Di SMK Negeri 1 Watampone Kabupaten Bone. Skripsi tidak diterbitkan. Bone; Fakultas Ilmu Sosial dan Ilmu Politik Universitas Hasanuddin.

Arikunto, S, 2006. Prosedur Penelitian Suatu Pendekatan Praktik. Ed Revisi VI, PT Rineka Cipta, Jakarta.

Becker BE, Mark A, dan D. Ulrich. 2001. HR Scorecard; Mengaitkan Manusia, Strategi dan Kinerja. Erlangga. Jakarta.

Busato, V.V, et al, 1999. Intellectual Ability, Learning Style, Personality Achievement Motivation And Academic Succes Of Psychology Student In Higher Education. Journal of Personality and Individual Differences, 29 (2000), pp 1057-1068.

Ghozali, Imam. 2006. Aplikasi Analisis Mulvarite dengan SPSS. Semarang: BadanPenerbit Universitas Diponegoro.

Goleman, Daniel. 2002. Emotional Intelegence-Kecerdasan Emosional, Terjemahan Alex Tri Kancoro Widodo. Jakarta: PT. Gramedia.

Hornby, D. and Thomas, R., 1989, Towards a better standard of management. London.

Journal Of Personnel Management, Vol.21 No.1, pp.52-55, Pan,

Indrianto, N dan B. Supomo, 2002, Metodelogi Penelitian Bisnis, Yogyakarta, BPFEYogyakarta.

Ismail, F, 2015. Pengaruh Tipe Kepribadian, Pengalaman dan Penerimaan Perilaku Disfungsional Terhadap Audit Judgment. Jurnal Bisnis dan Manajemen, Vol 5, no 2, pp. 263-275.

Ismail, M.I, 2010. Kinerja dan Kompetensi Guru Dalam Pembelajaran. Jurnal Pendidikan, Vol 13, No 1, pp. 44-63.

Kak, Neeraj, Bart Burkhalter, and Merri-Ann Cooper, 2001, Measuring the Competence of Healthcare Providers, Issue Paper, Volume No. 2, Issue 1, pp.3-23.

Kheruniah, A.E, 2013. A teacher Personality Competence Contribution To A Student Study Motivation And Discipline To Fiqh Lesson. Journal Of Scientific \& Technology Research, Vol 2, Issue 2, pp. 108-112.

Kreitner, R \& Knicki, A. 2005. Perilaku Organisasi. Salemba Empat, Jakarta. 
Lembaga Penelitian Pengembangan Keilmuan Guru Besar. 2013, Pemetaan Kompetensi Pedagogik, Profesional, Kepribadian dan Sosial Guru Fisika SMA/MA di Daerah Istimewa Yogyakarta. Yogyakarta; Universitas Negeri Yogyakarta.

Martina, K, U. Hana and F. Jiri, 2012. Identification Of Manajerial Competencies in Knowledge-Based Organizations. Journal of Competitiveness, Vol 4, Issue 1, pp. 129-142.

Martinez, M.C.M, 2005. The Perceived Competency Of Hispanic Teachers In Teaching Classes Of Diversity Is a Function Of Demografic and Personality Traits. Tesis tidak diterbitkan. Texas: The University Of Texas Pan American.

Mulyasa E. (2008). Menjadi Guru Profesional.Bandung: PT. Remaja Rosdakarya.

Naisaban, L. (2003). Psikologi Jung. Jakarta: Grasindo.

Nana Syaodih Sukmadinata. (2009). Metode Penelitian Pendidikan. Bandung: Rosdakarya.

Nicholson, I.A.M, 1996. Moral Projects \& Disciplinary Practies: Gordor Allport And The Development of American Personality Psychology, Tesis tidak diterbitkan. Ontario; Graduate Programme In Psychology York University North York.

Nugroho, P.I, L Suhartini, T.E Laksana, 2008. Pengaruh Kemampuan intelektual dan Kemampuan Emosional Terhadap Kinerja Auditor Melalui Kepuasaan Kerja Sebagai Variabel Intervening. Jurnal Ekonomi dan Bisnis, Vol XIV, No 2, pp. 107-122.

Peraturan Menteri Pendidikan Nasional Republik Indonesia Nomor 16 Tahun 2007 Tentang Standar Kualifikasi Akademik dan Kompetensi Guru.

Purwanto, Ngalim. 2003.Psikologi Pendidikan. Bandung: PT Remaja Rosdakarya.

Quigley, K, 2003. The Relationship Between Personality Factors and Team Member Competencies. Tesis tidak diterbitkan. Arizona; University Of Phoenix.

Rachman, M.M, 2012. April. Pengaruh Kemampuan Intelektual , Pembelajaran Individual dan Internal Locus Of Control Terhadap Kompetensi dan Kinerja Dosen. Majalah ekonomi, XXII, No 1, pp 91-105.

Raka, J.T. 1980. Pedoman Umum Alat Penilaian Kemampuan Guru dan Dosen. Jakarta: Dirjen Pendidikan Tinggi Depdikbud.

Robbins SP, dan Judge. 2007. Perilaku Organisasi, Jakarta: Salemba Empat.

Robbins, Stephen P. 2001.Perilaku Organisasi Jilid I. Yogyakarta: Aditya Media.

R. Palan , 2007. Competency Management. PPM Indonesia : Jakarta

Sari, D.A. 2010.Uji Validitas Alat ukur Big Personality (adaptasi dari IPIP) Pada Mahasisiwa Universitas Islam Negeri Syarif Hidayatullah. Skripsi tidak diterbitkan. Jakarta ; Fakultas Psikologi Universitas Islam Negeri Syarif Hidayatullah.

Sekaran, Uma, 2006. Metodelogi Penelitian Untuk Bisnis, Jakarta: Salemba Empat.

Smith, T.W, C.E Baron and J.L Grove, 2014. Personality, Emotional Adjustment And Cardiovaskular Risk: Marriage As a Merchanism. Journal of Personality, 82: 6, pp 502-514.

Spencer Lyle M. and Signe M Spencer, 1993. Competency work, Model for Superior Perform. Jhon Wiley and Son.Inc

Stone dan Broke. (1995). Competency ict. Inggris: Brust.

Sugiyono 2010.Metode Penelitian Pendidikan, Cetakan ke 10.Bandung: CV Alfa Beta. 
Suparno, E, 2005. Pengaruh Kompetensi , Motivasi Kerja dan Kecerdasan Emosional Guru Terhadap Kinerja Guru di SMP Negeri se-Rayon Barat Kabupaten Sragen. http:etd.eprints.uns.ac.id.

Sullaida, 2013. Pengaruh Kemampuan, Kerpribadian dan Semangat Kerja Karyawan PT. Telkom Cabang Lhokseumawe. Jurnal Visioner \& Strategis, Vol 2, No 1, pp 83-93.

Tilaar, H A R. 2002.Pendidikan Untuk Masyarakat Indonesia Baru. Jakarta: Grasindo. Wibowo. (2007). Manajemen Kinerja. Jakarta: PT Raja Grafindo Persada Hal 86.

Widarjono, A, 2010. Analisis Statistika Multivariat Terapan. Edisi ke empat. Yogyakarta: UPP STIM YKPN.

Yuliana, Eka. 2006. Pengaruh Kemampuan Intelektual dan Motivasi Kerja Terhadap Kinerja Guru Mata Diklat Produktif Penjualan Di SMK Bisnis dan Manajemen. Tesis. (Tidak Dipublikasikan), Semarang: Universitas Diponegoro.

Zwell, Michael, (2000). Creating a Culture of Competence. New York: John Wiley \& Sons, Inc. 